\title{
PROBABLE ERRORS IN THE SIMULTANEOUS MEASUREMENT OF SEPARATE KIDNEY FUNCTIONS
}

\author{
By CALVIN KLOPP, NELSON F. YOUNG, AND HOWARD C. TAYLOR, JR. \\ (From the Memorial Hospital, New York City)
}

(Received for publication June 2, 1944)

The methods developed by Smith and his associates have made possible the separate measurement of glomerular filtration, the effective renal blood flow, and the total functioning mass of tubular tissue (1). During a recent study of the effects of certain steroids on these renal functions in man, it became apparent that their determination could not always be made simultaneously since the administration of test substances for the determination of one function interfered with the determination of another. The extent and manner of this interference is the subject of the present communication.

\section{METHODS}

A. The plasma clearance of mannitol $\left(\mathrm{C}_{\mathrm{M}}\right)$ was used as a measure of glomerular filtration (1). Plasma levels of the compound were maintained between 90 and $200 \mathrm{mgm}$. per cent.

B. The plasma clearance of p-amino hippuric acid (PAH) at levels of from 0.8 to $3.0 \mathrm{mgm}$. per $100 \mathrm{ml}$. plasma was used as an index of effective renal blood flow. At these levels, PAH is removed completely from the plasma in a single passage through the kidney (2).

C. The functioning tubular mass ( $\mathrm{Tm}$ ) was ascertained by two methods. These were: (1) p-Amino hippuric acid $T m$ (TmPAH), a measure of the maximum ability of the kidney tubules to secrete that substance (3); plasma levels greater than $44 \mathrm{mgm}$. per cent were maintained during the determination. (2) Glucose $\mathrm{Tm}\left(\mathrm{Tm}_{\mathrm{G}}\right)$, a measure of the maximum ability of the tubular cells to reabsorb glucose $(4,5)$ in the course of these determinations; plasma levels of glucose were maintained constantly above $300 \mathrm{mgm}$. per cent.

Solutions of the test substances were made before each determination from amounts calculated to be necessary to raise and maintain the desired concentration in the plasma (5). After preliminary trial procedures, these amounts were adjusted. Those solutions used for "priming" were run in by gravity through a No. 18 gauge needle as rapidly as possible. Those solutions used to maintain the desired plasma levels were given at about $4 \mathrm{ml}$. per minute and, after 15 minutes, blood and urine collections were begun.

Each function was estimated during 3 consecutive 10minute periods. Blood samples were taken at the onset and just prior to the completion of the last of these periods.
Urine was collected through an indwelling catheter and, after each collection, the bladder was washed out 2 times with $20 \mathrm{ml}$. of saline and $10 \mathrm{ml}$. of air. All chemical determinations were made within 36 hours of the clinical tests. Protein-free filtrates of plasma samples were made as soon as each test was completed.

\section{CLINICAL MATERIAL}

A heterogeneous group of 13 subjects was studied. These consisted of 3 normal women, 2 normal men, 1 woman with chronic hypertension, and another with carcinoma of the uterus, 1 male with Paget's disease of the bone, 1 with melanosarcoma, 1 with hypogonadism, and 1 each with cancer of the stomach, breast, and prostate. All subjects were afebrile and in good nutritional status.

\section{RESULTS}

\section{A. The relationship of the plasma concentration of glucose to the clearance of p-amino hippuric acid and mannitol}

Measurements of PAH clearance were first made in 4 subjects. When several days later these determinations were repeated, the values in 3 apparently had decreased by amounts varying from 16 to 63 per cent. This unusual finding was considered possibly due to the fact that an attempt was made during the latter determination to measure simultaneously the glucose $\mathrm{Tm}$ and for that purpose, it was necessary to maintain plasma levels of glucose at from 390 to $500 \mathrm{mgm}$. per cent (Table I).

It became necessary, therefore, to ascertain whether or not the renal clearance of PAH could have been affected merely by this increased concentration of glucose in the plasma, or due to some other factor which had developed between the first and second measurements. Accordingly, the $\mathrm{C}_{\mathrm{PAH}}$ was determined in the course of a single test in 3 subjects, both before and during the infusion of glucose. In 1 of these, the test was repeated. A decreased clearance of PAH was effected in 3 experiments within a few minutes after the plasma glucose 
level was raised to levels of from 390 to $520 \mathrm{mgm}$. per cent. This depression was constant in several consecutive 15-minute periods (Table I) and ranged from 30 to 80 per cent.

The possibility existed that the apparent depression of renal blood flow which had occurred when the plasma glucose level was increased might have been due to an interference in the determination of PAH by the presence of large concentrations of the sugar. However, known concentrations of PAH (0.5 to $5.0 \mathrm{mgm}$. per cent) in the presence of larger concentrations of glucose always could be quantitatively and completely recovered.

It is of interest to note that the clearance of mannitol, on the other hand, was not significantly affected by wide alterations in the plasma glucose level (Table I).

B. The relationship between the plasma concentrations of p-amino hippuric acid to the tubular resorption of glucose $\left(T m_{G}\right)$

Measurements of the tubular resorption of glucose were made in 5 individuals, at which time their plasma levels of p-amino hippuric acid ranged from 0.5 to $1.8 \mathrm{mgm}$. per cent. In 2 instances, an attempt was made on another day to measure simultaneously the $\mathrm{Tm}$ of glucose and of PAH. In the remaining 3, and also in 1 of the preceding 2 individuals, the measurement of $\mathrm{Tm}_{\mathrm{PAH}}$ was made simultaneously with that of glucose, immediately after the glucose $\mathrm{Tm}$ had been determined alone. During this determination, the concentrations of PAH in the plasma necessarily were increased to levels of from 44 to $81 \mathrm{mgm}$. per cent. Under these circumstances, the value of glucose $\mathrm{Tm}$ apparently was increased significantly in 3 individuals by from 22 to 68 per cent (Table II). In these 3 subjects, the increased $\mathrm{Tm}$ values persisted until the plasma concentration of PAH again was sharply reduced.

The addition of $\mathrm{PAH}$ in concentrations of from 1 to $100 \mathrm{mgm}$. per cent to solutions of glucose was not found to interfere with the quantitative determinations of the sugar.

\section{The relationship of the plasma level of glucose to the apparent tubular secretion of $P A H$}

In 8 subjects, an attempt was made to ascertain the effects of high concentrations of glucose on the apparent tubular secretion of PAH. These measurements were obtained on the same day in all but 2 instances. In the course of the

TABLE I

The effect of the plasma concentration of glucose on the clearance of p-amino hippuric acid and mannitol

\begin{tabular}{|c|c|c|c|c|c|c|}
\hline \multirow{2}{*}{ Subject } & \multirow{2}{*}{ Teats made on } & \multicolumn{3}{|c|}{ Plasma concentration } & \multicolumn{2}{|c|}{ Plasma clearance } \\
\hline & & Glucose & PAH & Mannitol & PAH & Mannitol \\
\hline $\begin{array}{l}\text { M. H. } \\
\text { Hypogonadism }\end{array}$ & Separate days & $\begin{array}{l}\text { Fasting } \\
495\end{array}$ & $\begin{array}{l}\text { per cer } \\
2.3 \\
1.7\end{array}$ & $\begin{array}{l}180 \\
176\end{array}$ & $\begin{array}{l}m l \\
387 \\
162\end{array}$ & $\begin{array}{l}81 \\
78\end{array}$ \\
\hline $\begin{array}{l}\text { M. F. } \\
\text { Hypertension }\end{array}$ & Separate days & $\begin{array}{c}\text { Fasting } \\
500\end{array}$ & $\begin{array}{l}2.9 \\
1.6\end{array}$ & $\begin{array}{l}200 \\
166\end{array}$ & $\begin{array}{l}215 \\
180\end{array}$ & $\begin{array}{l}73 \\
75\end{array}$ \\
\hline $\begin{array}{l}\text { E. C. } \\
\text { Normal }\end{array}$ & Separate days & $\begin{array}{c}\text { Fasting } \\
390\end{array}$ & $\begin{array}{l}1.4 \\
1.6\end{array}$ & $\begin{array}{l}175 \\
150\end{array}$ & $\begin{array}{l}635 \\
235\end{array}$ & $\begin{array}{l}107 \\
120\end{array}$ \\
\hline $\begin{array}{l}\text { A. B. } \\
\text { Melanosarcoma }\end{array}$ & Separate days & $\underset{455}{\text { Fasting }}$ & $\begin{array}{l}1.6 \\
1.2\end{array}$ & $\begin{array}{l}147 \\
140\end{array}$ & $\begin{array}{l}543 \\
681\end{array}$ & $\begin{array}{l}129 \\
119\end{array}$ \\
\hline $\begin{array}{l}\text { F. S. } \\
\text { Cancer stomach }\end{array}$ & Same day & $\underset{520}{\text { Fasting }}$ & $\begin{array}{l}0.61 \\
0.52\end{array}$ & $\begin{array}{r}99 \\
115\end{array}$ & $\begin{array}{l}630 \\
433\end{array}$ & $\begin{array}{l}112 \\
122\end{array}$ \\
\hline \multirow[t]{2}{*}{$\begin{array}{l}\text { E. C. } \\
\text { Normal }\end{array}$} & Same day & $\begin{array}{c}\text { Fasting } \\
450\end{array}$ & $\begin{array}{l}1.5 \\
1.8\end{array}$ & $\begin{array}{l}135 \\
130\end{array}$ & $\begin{array}{l}750 \\
170\end{array}$ & $\begin{array}{l}100 \\
126\end{array}$ \\
\hline & Same day & $\begin{array}{c}\text { Fasting } \\
390\end{array}$ & $\begin{array}{l}1.2 \\
1.3\end{array}$ & $\begin{array}{l}123 \\
128\end{array}$ & $\begin{array}{l}830 \\
372\end{array}$ & $\begin{array}{l}115 \\
121\end{array}$ \\
\hline $\begin{array}{l}\text { G. F. } \\
\text { Cancer, prostate }\end{array}$ & Same day & $\begin{array}{c}\text { Fasting } \\
346\end{array}$ & $\begin{array}{l}1.35 \\
1.2\end{array}$ & $\begin{array}{l}123 \\
135\end{array}$ & $\begin{array}{l}728 \\
932\end{array}$ & $\begin{array}{l}122 \\
132\end{array}$ \\
\hline
\end{tabular}


TABLE II

The effect of the plasma concentration of PAH on the tubular reabsorption of glucose

\begin{tabular}{|c|c|c|c|c|c|c|}
\hline \multirow{2}{*}{ Subject } & \multirow{2}{*}{ Tests made on } & \multicolumn{3}{|c|}{ Plasma level } & \multicolumn{2}{|c|}{$\mathbf{T m}$} \\
\hline & & PAH & Mannitol & Glucose & Glucose & PAH \\
\hline & & \multicolumn{3}{|c|}{ mem. per cent } & \multicolumn{2}{|c|}{ mgm. per minute } \\
\hline $\begin{array}{l}\text { M. H. } \\
\text { Hypogonadism }\end{array}$ & Separate days & $\begin{array}{l}70.0 \\
1.65\end{array}$ & $\begin{array}{l}205 \\
190\end{array}$ & $\begin{array}{l}\mathbf{5 5 0} \\
\mathbf{5 2 0}\end{array}$ & $\begin{array}{l}185 \\
152\end{array}$ & 52 \\
\hline \multirow[t]{2}{*}{$\begin{array}{l}\text { E. C. } \\
\text { Normal }\end{array}$} & Separate days & $\begin{array}{c}66.5 \\
1.30\end{array}$ & $\begin{array}{l}185 \\
145\end{array}$ & $\begin{array}{l}495 \\
350\end{array}$ & $\begin{array}{l}215 \\
175\end{array}$ & 70 \\
\hline & Same day & $\begin{array}{r}1.8 \\
81.0\end{array}$ & $\begin{array}{l}130 \\
155\end{array}$ & $\begin{array}{l}450 \\
380\end{array}$ & $\begin{array}{l}172 \\
290\end{array}$ & 55 \\
\hline $\begin{array}{l}\text { F. S. } \\
\text { Cancer, stomach }\end{array}$ & Same day & $\begin{array}{r}0.5 \\
44.0\end{array}$ & $\begin{array}{l}115 \\
136\end{array}$ & $\begin{array}{l}520 \\
570\end{array}$ & $\begin{array}{l}321 \\
440\end{array}$ & 72 \\
\hline $\begin{array}{l}\text { A. B. } \\
\text { Melanosarcoma }\end{array}$ & Same day & $\begin{array}{r}1.2 \\
68.0\end{array}$ & $\begin{array}{l}140 \\
140\end{array}$ & $\begin{array}{l}455 \\
433\end{array}$ & $\begin{array}{l}297 \\
314\end{array}$ & 78.9 \\
\hline $\begin{array}{l}\text { G. F. } \\
\text { Cancer, prostate }\end{array}$ & Same day & $\begin{array}{r}1.2 \\
55.0\end{array}$ & $\begin{array}{l}135 \\
137\end{array}$ & $\begin{array}{l}346 \\
375\end{array}$ & $\begin{array}{l}340 \\
351\end{array}$ & 81.3 \\
\hline
\end{tabular}

determinations, the plasma levels of $\mathrm{PAH}$ were maintained at concentrations of from 54 to 176 mgm. per cent.

When the plasma glucose level was raised from the fasting levels to that necessary to ascertain the $\mathrm{Tm}$ value (from 375 to $533 \mathrm{mgm}$. per cent), a decrease in the $\mathrm{Tm}_{\mathrm{PAH}}$ was effected in 3 individuals. This decrease ranged from 17 to 48 per cent. No change occurred in 1 subject, and in the remaining 4 , the decrease probably was not significant (Table III).

D. The relationship between the plasma levels of glucose and PAH and the clearance of mannitol

In the course of the determinations described, whenever the plasma concentrations of both

TABLE III

The effect of the plasma concentration of glucose on the tubular secretion of $P A H$

\begin{tabular}{|c|c|c|c|c|c|c|}
\hline \multirow{2}{*}{ Subject } & \multirow{2}{*}{ Tests made on } & \multicolumn{3}{|c|}{ Plasma level } & \multicolumn{2}{|c|}{$\operatorname{Tm}$} \\
\hline & & Glucose & PAH & Mannitol & PAH & Glucose \\
\hline $\begin{array}{l}\text { C. W. } \\
\text { Normal }\end{array}$ & Same day & $\begin{array}{c}\text { Fasting } \\
394\end{array}$ & $\begin{array}{l}\text { per cen } \\
81 \\
81\end{array}$ & $\begin{array}{l}130 \\
142\end{array}$ & $\begin{array}{c}\text { mgm } \\
78.0 \\
74.1\end{array}$ & $\begin{array}{l}184 \\
184 \text { sute }\end{array}$ \\
\hline $\begin{array}{l}\text { E. S. } \\
\text { Cancer, breast }\end{array}$ & Same day & $\underset{533}{\text { Fasting }}$ & $\begin{array}{l}170 \\
176\end{array}$ & $\begin{array}{l}218 \\
223\end{array}$ & $\begin{array}{l}34.6 \\
17.9\end{array}$ & 190.9 \\
\hline $\begin{array}{l}\text { E. C. } \\
\text { Normal }\end{array}$ & Same day & $\begin{array}{l}\text { Fasting } \\
413\end{array}$ & $\begin{array}{l}86.5 \\
66.5\end{array}$ & $\begin{array}{l}150 \\
148\end{array}$ & $\begin{array}{l}81.8 \\
74.2\end{array}$ & 234.3 \\
\hline $\begin{array}{l}\text { F. G. } \\
\text { Normal }\end{array}$ & Same day & $\begin{array}{c}\text { Fasting } \\
\mathbf{5 2 0}\end{array}$ & $\begin{array}{l}73.0 \\
54.0\end{array}$ & $\begin{array}{l}160 \\
163\end{array}$ & $\begin{array}{l}89.6 \\
74.3\end{array}$ & 360 \\
\hline $\begin{array}{l}\text { R. M. } \\
\text { Normal }\end{array}$ & Same day & $\underset{525}{\text { Fasting }}$ & $\begin{array}{l}80.0 \\
63.0\end{array}$ & $\begin{array}{l}150 \\
150\end{array}$ & $\begin{array}{l}80.0 \\
76.5\end{array}$ & 310 \\
\hline $\begin{array}{l}\text { D. F. } \\
\text { Paget's disease }\end{array}$ & Same day & $\begin{array}{l}\text { Fasting } \\
492\end{array}$ & $\begin{array}{l}72.0 \\
68.0\end{array}$ & $\begin{array}{l}150 \\
160\end{array}$ & $\begin{array}{l}96.4 \\
76.8\end{array}$ & 260 \\
\hline $\begin{array}{l}\text { G. F. } \\
\text { Cancer, prostate }\end{array}$ & Separate days & $\underset{375}{\text { Fasting }}$ & $\begin{array}{l}59.0 \\
55.0\end{array}$ & $\begin{array}{l}130 \\
137\end{array}$ & $\begin{array}{l}90.4 \\
81.3\end{array}$ & 351 \\
\hline $\begin{array}{l}\text { A. B. } \\
\text { Melanosarcoma }\end{array}$ & Separate days & $\begin{array}{c}\text { Fasting } \\
433\end{array}$ & $\begin{array}{l}67.5 \\
68.0\end{array}$ & $\begin{array}{l}140 \\
140\end{array}$ & $\begin{array}{l}78.2 \\
78.9\end{array}$ & 314 \\
\hline
\end{tabular}


TABLE IV

The effect of the plasma concentration of glucose and $P A H$ on the glomerular filtration of mannitol

\begin{tabular}{|c|c|c|c|c|c|}
\hline \multirow{2}{*}{ Subject } & \multirow{2}{*}{ Tests made on } & \multicolumn{3}{|c|}{ Plasma concentration } & \multirow{2}{*}{$\begin{array}{l}\text { Mannito } \\
\text { clearance }\end{array}$} \\
\hline & & Glucose & PAH & Mannitol & \\
\hline \multirow[t]{2}{*}{$\begin{array}{l}\text { E. C. } \\
\text { Normal }\end{array}$} & Separate days & $\begin{array}{l}\text { Fasting } \\
\mathbf{3 8 0}\end{array}$ & $\begin{array}{c}\text { per cent } \\
2.0 \\
81.0\end{array}$ & $\begin{array}{l}140 \\
155\end{array}$ & $\begin{array}{l}100 \\
145\end{array}$ \\
\hline & Same day & $\begin{array}{c}\text { Fasting } \\
413\end{array}$ & $\begin{array}{r}1.9 \\
66.5\end{array}$ & $\begin{array}{l}143 \\
148\end{array}$ & $\begin{array}{l}102 \\
122\end{array}$ \\
\hline $\begin{array}{l}\text { F. S. } \\
\text { Cancer, stomach }\end{array}$ & Same day & $\begin{array}{l}\text { Fasting } \\
560\end{array}$ & $\begin{array}{r}1.8 \\
44.0\end{array}$ & $\begin{array}{l}100 \\
140\end{array}$ & $\begin{array}{l}112 \\
145\end{array}$ \\
\hline $\begin{array}{l}\text { D. F. } \\
\text { Paget's disease }\end{array}$ & Separate days & $\begin{array}{l}\text { Fasting } \\
492\end{array}$ & $\begin{array}{r}2.1 \\
68.0\end{array}$ & $\begin{array}{l}143 \\
163\end{array}$ & $\begin{array}{l}86.5 \\
96.0\end{array}$ \\
\hline $\begin{array}{l}\text { G. W. } \\
\text { Normal }\end{array}$ & Same day & $\begin{array}{l}\text { Fasting } \\
394\end{array}$ & $\begin{array}{r}1.6 \\
81.0\end{array}$ & $\begin{array}{l}135 \\
142\end{array}$ & $\begin{array}{r}90 \\
107\end{array}$ \\
\hline $\begin{array}{l}\text { E. S. } \\
\text { Cancer, breast }\end{array}$ & Same day & $\underset{533}{\text { Fasting }}$ & $\begin{array}{c}2.8 \\
165.0\end{array}$ & $\begin{array}{l}200 \\
223\end{array}$ & $\begin{array}{l}49 \\
72\end{array}$ \\
\hline $\begin{array}{l}\text { F. G. } \\
\text { Normal }\end{array}$ & Same day & $\begin{array}{c}\text { Fasting } \\
520\end{array}$ & $\begin{array}{r}1.7 \\
54.0\end{array}$ & $\begin{array}{l}157 \\
163\end{array}$ & $\begin{array}{l}102 \\
120\end{array}$ \\
\hline
\end{tabular}

glucose and PAH were simultaneously increased, there occurred in all of 6 subjects studied, a significant increase of the mannitol clearance. This increase ranged from 11 to 47 per cent (Table IV). That this finding was not due to any interference with the chemical determinations of mannitol was demonstrated by the quantitative recoveries of that compound from solutions containing high concentrations of both glucose and PAH.

\section{COMMENT}

The rate of glomerular filtration $\left(C_{M}\right)$, effective renal blood flow $\left(\mathrm{C}_{\mathrm{PAH}}\right)$, and apparent tubular excretory or absorption mass ( $T \mathrm{~m}_{\mathrm{PAH}}$ and $T \mathrm{~m}_{\mathrm{G}}$ ) probably are constant for a given individual who remains untreated or does not suffer from a progressive renal or vascular disease (5). For this reason, their measurement has been advocated to evaluate expected changes of separate components of kidney function. It would appear, however, from the present study that the value of certain functions sometimes may be altered by an attempt to measure simultaneously a second renal capacity. Hence, unless successive observations on the same subject are repeated under identical conditions, the determinations frequently may be in error.
It is impossible to explain definitely the alterations of $\mathrm{Tm}$ and clearance values when the plasma concentrations of glucose or PAH reach high levels. With regard to the mannitol clearance, which is uncomplicated by tubular transfer phenomena, one must look to changes in the glomerular apparatus for the explanation of increased $C_{M}$ values when plasma concentrations of both glucose and PAH are raised. Specifically, one must consider changes in renal blood flow and distribution due to alterations in tone of the afferent and efferent arterioles, changes in systemic blood pressure and the possibility of variations in the number of functioning nephrons under the various conditions.

The alterations in those functional activities which depend in part or wholly on the active transfer mechanisms in the cells of the proximal segments of the tubules are more difficult to interpret. Recently there has been demonstrated (6) a nonspecific interference of sodium chloride and potassium chloride with the tubular reabsorption of ascorbic acid. These findings and those of the present study seem to indicate a competition of chemically unrelated substances for the cellular transfer mechanisms. The actual characteristics of this competition are not clear but their functional significance is potentially very great. 


\section{CONCLUSIONS}

1. High plasma concentrations of glucose may decrease the apparent renal blood flow as determined by the clearance of $\mathrm{p}$-amino hippuric acid.

2. High plasma concentrations of glucose do not alter the rate of glomerular filtration $\left(C_{M}\right)$ but may decrease the maximum ability of the tubules to secrete p-amino hippuric acid.

3. High plasma concentrations of p-amino hippuric acid may increase the apparent tubular resorption of glucose.

4. When the plasma concentrations of both glucose and p-amino hippuric acid are raised, increased values of apparent glomerular filtration are obtained.

5. The simultaneous measurement of more than one renal function frequently may give erroneous values.

\section{BIBLIOGRAPHY}

1. Smith, W. W., Finkelstein, N., and Smith, H. W., Renal excretion of hexitols (sorbitol, mannitol, and dulcitol) and their derivatives (sorbiton, isomannide, and sorbide) and of endogenous creatinine-like chromogen in dog and man. J. Biol. Chem., 1940, $135,231$.

2. Finkelstein, N., Aliminosa, F. M., and Smith, H. W., The renal clearances of hippuric acid and pyridone derivatives. Am. J. Physiol., 1941, 133, 276.

3. Smith, H. W., Personal communication.

4. Shannon, J. A., and Fisher, S., The renal tubular reabsorption of glucose in the normal dog. Am. J. Physiol., 1938, 122, 765.

5. Goldring, W., Chassis, H., Ranges, H. A., and Smith, H. W., Relations of effective renal blood flow and glomerular filtration to tubular excretory mass in normal man. J. Clin. Invest., 1940, 19, 739.

6. Selkurt, E. E., and Houck, C. R., The effect of sodium and potassium chloride on the renal clearance of ascorbic acid. Am. J. Physiol., 1944, 141, 423. 